[Original]

\title{
Responses of Autonomic Cardiovascular Systems Induced by Hypoxia: Rebound Phenomenon and Species Difference
}

\author{
Haruhisa HIRAKAWA and Yoshiaki HAYASHIDA \\ Department of Systems Physiology, Institute of Industrial Ecological Sciences, University of Occupational \\ and Environmental Health, Japan. Yahatanishi-ku, Kitakyushu 807-8555, Japan
}

Abstract: The rebound tachycardia, transient increase in heart rate (HR) that was observed immediately after the cessation of hypoxia was investigated. Whether the cardiovascular responses induced by hypoxia depend on species difference is also discussed. Wistar rats were chronically instrumented for measurements of arterial blood pressure (ABP), HR and renal sympathetic nerve activity (RSNA), and then subjected to hypocapnic (Hypo), isocapnic (Iso) or hypercapnic (Hyper) hypoxia. Iso did not affect mean $\mathrm{ABP}(\mathrm{MAP})$ or HR, whereas Hypo decreased MAP and increased HR, and Hyper increased MAP and decreased HR. RSNA increased in each hypoxia. After the cessation of Iso and Hyper, HR transiently increased and then returned to that of the control. This HR response did not parallel the changes in RSNA, suggesting that "rebound" tachycardia is not due to a sympathetic but rather a parasympathetic mechanism. Although it has been generally believed that cardiovascular responses to systemic hypoxia depend on the species, there was little difference between the results observed in this study and those in previous studies under similar experimental conditions. Accordingly, we suggest that the cardiovascular responses to systemic hypoxia do not depend on species difference but rather on differences in experimental design.

Key words:cardiovascular response, autonomic nervous system, systemic hypoxia, species difference, rebound tachycardia.

(Received 18 January 2002, accepted 8 April 2002 )

\section{Introduction}

Systemic hypoxia activates central and/or peripheral chemoreceptors, which produce changes in cardiovascular and respiratory functions. Cardiovascular and autonomic responses are modulated secondarily by respiratory change $[1-4]$ which is known to be biphasic; i.e. there is an initial fast increase in ventilation followed by a slow decrease to a value above the normoxic level[5]. Furthermore, it has been suggested that the autonomic nervous system plays an important role in cardiovascular responses to acute hypoxia [1,6-9]. Thus, cardiovascular and autonomic responses to hypoxia have been extensively investigated 
in a number of species, but results are conflicting. The variability of these results is thought to reflect the species difference, however, there are differences in responses even in the same species. Possible reasons for the inability to provide unambiguous results include a paucity of studies employing direct autonomic nerve recordings in conscious animals, failure to consider the effect of concomitant alterations in $\mathrm{PaCO}_{2}$ and duration of stimulus.

Many physiological systems are known to respond to the application and removal of a stimulus by transiently "overshooting" the steady state level that is eventually achieved[10]. One of physiological overshoots which has attracted many researchers since it was first described is postvagal tachycardia; i.e. a brief increase in heart rate $(\mathrm{HR})$ that follows the bradycardia produced by the use of vagal stimulation [11]. In order to delineate the mechanism of this rebound phenomenon, many studies have been carried out using electrical stimulation of the vagosympathetic complex or cardiopulmonary nerve. However, involvement of the complicating factors is a drawback to such an electrical stimulation method. Therefore, the application and removal of "natural" stimulus would provide some evidence for the role of the autonomic nervous system in the rebound phenomenon, because the autonomic nervous system is involved in cardiovascular responses to acute hypoxia.

Accordingly, the purpose of the present study was to investigate the autonomic cardiovascular responses to the application and removal of systemic hypoxia with 3 distinct levels of $\mathrm{CO}_{2}$ in unanesthetized rats by recordings of blood pressure, $\mathrm{HR}$ and sympathetic nerve activity throughout the experiment. We then analyzed the rebound phenomenon of the cardiovascular responses to the application and removal of systemic hypoxia. Finally, we reevaluated the cardiovascular responses to systemic hypoxia, which had been previously reported in various species, taking the methods of ours and theirs into account.

\section{Materials and Methods}

All of the protocols and surgical procedures used in this study were performed in accordance with the guidelines specified for institutional animal care and use of the University of Occupational and Environmental Health, Japan.

\section{Animal preparation}

Male Wistar rats weighing between 350 and $450 \mathrm{~g}$ were used in these experiments. Animals were prepared for recordings of renal sympathetic nerve activity (RSNA) and electrocardiogram (ECG), arterial and venous catheterization as described previously [9]. Briefly, rats were anesthetized with pentobarbital sodium $(50 \mathrm{mg} / \mathrm{kg}$, ip). Through a left flank incision, a branch of the left renal nerve running on or beside the renal artery was exposed and dissected free from surrounding tissue under a dissecting microscope. Stainless steel bipolar hooked electrodes were used to record RSNA. The nerve and electrodes were stabilized with a two-component silicone rubber gel (Wacker silicone 604, Wacker-Chemie, Germany). 
After the gel hardened, the incision was closed. To record ECG, a pair of Teflon-coated stainless steel wires was implanted under the skin at mid-chest. Heparin-filled polyethylene catheters were inserted into the abdominal aorta from the right femoral artery to measure arterial blood pressure $(\mathrm{ABP})$ and into the inferior vena cava from the right femoral vein to administer drugs. All of the leads and catheters were routed subcutaneously to exit at the nape. After the operation, the rat was kept under a constant temperature $\left(25^{\circ} \mathrm{C}\right)$ and received an infusion of Ringer solution containing D-sorbitol and antibiotics.

\section{Experimental protocols}

More than $48 \mathrm{~h}$ after implantation of the electrodes and catheters, each rat was placed in a home cage inside an airtight acrylic chamber $(40 \times 25 \times 40 \mathrm{~cm})$ with two holes. One hole, located at the top of one wall of the chamber, was connected to a multi-flowmeter(MODEL1203, KOFLOC, Japan) and used to deliver a gas mixture (air, $\mathrm{N}_{2}$ and $\mathrm{CO}_{2}$ : total $20 \ell / \mathrm{min}$ ) into the chamber. The second hole, which was located at the bottom of the opposite wall of the chamber, was used to flush out the gas mixture. All of the rats were allowed 30-60 min to adjust to their environment in the airtight acrylic chamber ventilated by air, and control measurements were commenced when stable ABP, HR and RSNA were observed. After control measurements were taken for $30 \mathrm{~min}$, air was replaced by a hypoxic gas mixture for $30 \mathrm{~min}$ according to one of the experimental protocols. The hypoxic gas mixture was then replaced by air for a recovery period of $30 \mathrm{~min}$. Each experiment was performed on a separate day between 0900 and $1200 \mathrm{~h}$, and the order of experimentation was randomized. The temperature within the chamber was maintained at $25^{\circ} \mathrm{C}$.

\section{Hypoxic exposure}

1. Hypocapnic hypoxia (Hypo, $n=7)$ : The chamber was ventilated by a hypoxic gas mixture $\left(10 \% \mathrm{O}_{2}\right.$ in $\left.\mathrm{N}_{2}\right)$ for $30 \mathrm{~min}$. The flow of air and $\mathrm{N}_{2}$ was regulated by a multi-flowmeter and the $\mathrm{O}_{2}$ and $\mathrm{CO}_{2}$ levels within the chamber were continuously monitored with a gas analyzer(Respina 1H26, NEC San-ei, Japan). It took an average of $5 \mathrm{~min}$ to completely replace the gas mixture in the chamber.

2 . Isocapnic hypoxia (Iso, $n=7$ ): The experimental protocol was identical to the Hypo protocol except that $\mathrm{CO}_{2}$ was added to the gas mixture in a concentration $(3-4 \%)$ that was sufficient to maintain $\mathrm{PaCO}_{2}$ close to that measured during the control period.

3 . Hypercapnic hypoxia (Hyper, $n=6)$ : The chamber was ventilated by a gas mixture $(10 \%$ $\mathrm{O}_{2}+6.5-7 \% \mathrm{CO}_{2}$ in $\mathrm{N}_{2}$ ). All other experimental procedures were the same as in the Hypo and Iso protocols.

\section{Blood sampling}

For the analysis of arterial blood gases, $0.08 \mathrm{ml}$ of blood was drawn during the control period and $20 \mathrm{~min}$ after the start of hypoxic exposure. Blood samples were analyzed for $\mathrm{pH}$, 
$\mathrm{PaO}_{2}$ and $\mathrm{PaCO}_{2}$ by a gas analyzer (ABL-30, Radiometer, Denmark).

\section{Data recording}

The original RSNA was amplified and filtered $(50-1000 \mathrm{~Hz})$ by a differential low-noise amplifier (AVB-11, Nihon Kohden, Japan) and monitored continuously on an oscilloscope (VC-11, Nihon Kohden, Japan), a pulse counter(EN-601J, Nihon Kohden, Japan) and an audio speaker. Mean RSNA was obtained by integration of the rectified signal with a time constant of $0.1 \mathrm{sec}$ through a voltage integrator (EI-601G, Nihon Kohden, Japan). After the end of the experiment, the background noise was determined, when nerve activity was eliminated by increasing ABP with phenylephrine (4-10 $\mu \mathrm{g} / \mathrm{kg})$. The background noise was subtracted from the integrated RSNA obtained during the experiment. To quantify the RSNA response, percentage changes in the response were calculated by taking the mean of these values during the control period as $100 \%$ RSNA. HR was obtained from a cardiotachometer triggered by the R wave of the ECG signal. For later analysis, the analog outputs of RSNA, mean RSNA, ABP, HR and ECG were recorded on a digital tape recorder(PC 116, SONY, Japan).

The respiration waveform was extracted from recordings of the blood pressure wave using an analog bandpass filter (E-3201A, NF Electronic Instruments, Japan) with an attenuation ratio of $1 / 3$ per octave. The center frequency was initially set at around $1.4 \mathrm{~Hz}$, since the normal ventilatory frequency in the conscious rat ranged from 0.9 to $2.0 \mathrm{~Hz}(54-120 / \mathrm{min})$. The optimal center frequency was then searched for manually to obtain a smooth curve with the largest possible amplitude, which was displayed on a chart to calculate the respiratory frequency $[9,12]$.

\section{Statistical analysis}

Values are expressed as mean $\pm \mathrm{SE}$. Between-group and within-group comparisons were performed using a two-way analysis of variance (ANOVA)combined with Fisher's leastsignificant difference test. A value of $P<0.05$ was considered statistically significant.

\section{Results}

\section{Blood gas analysis and respiration}

Fig. 1 shows the mean values of arterial $\mathrm{pH}, \mathrm{PaCO}_{2}, \mathrm{PaO}_{2}(\mathrm{~A})$ and respiratory frequency (B) during the control period and in the three hypoxic periods. Exposure to $10 \% \mathrm{O}_{2}$ resulted in a substantial decrease in $\mathrm{PaO}_{2}$. In the animals that were exposed solely to the hypoxic stimulus, profound respiratory alkalosis developed, as shown by a fall in $\mathrm{PaCO}_{2}$ and an increase in arterial $\mathrm{pH}$. When $3-4 \% \mathrm{CO}_{2}$ was added to the hypoxic air, $\mathrm{PaCO}_{2}$ was maintained to be isocapnic. When $6.5-7 \% \mathrm{CO}_{2}$ was added to the hypoxic gas mixture, hypercapnic acidosis developed in addition to hypoxia. The mean respiratory frequency during the 
A

$(\mathrm{mmHg})$
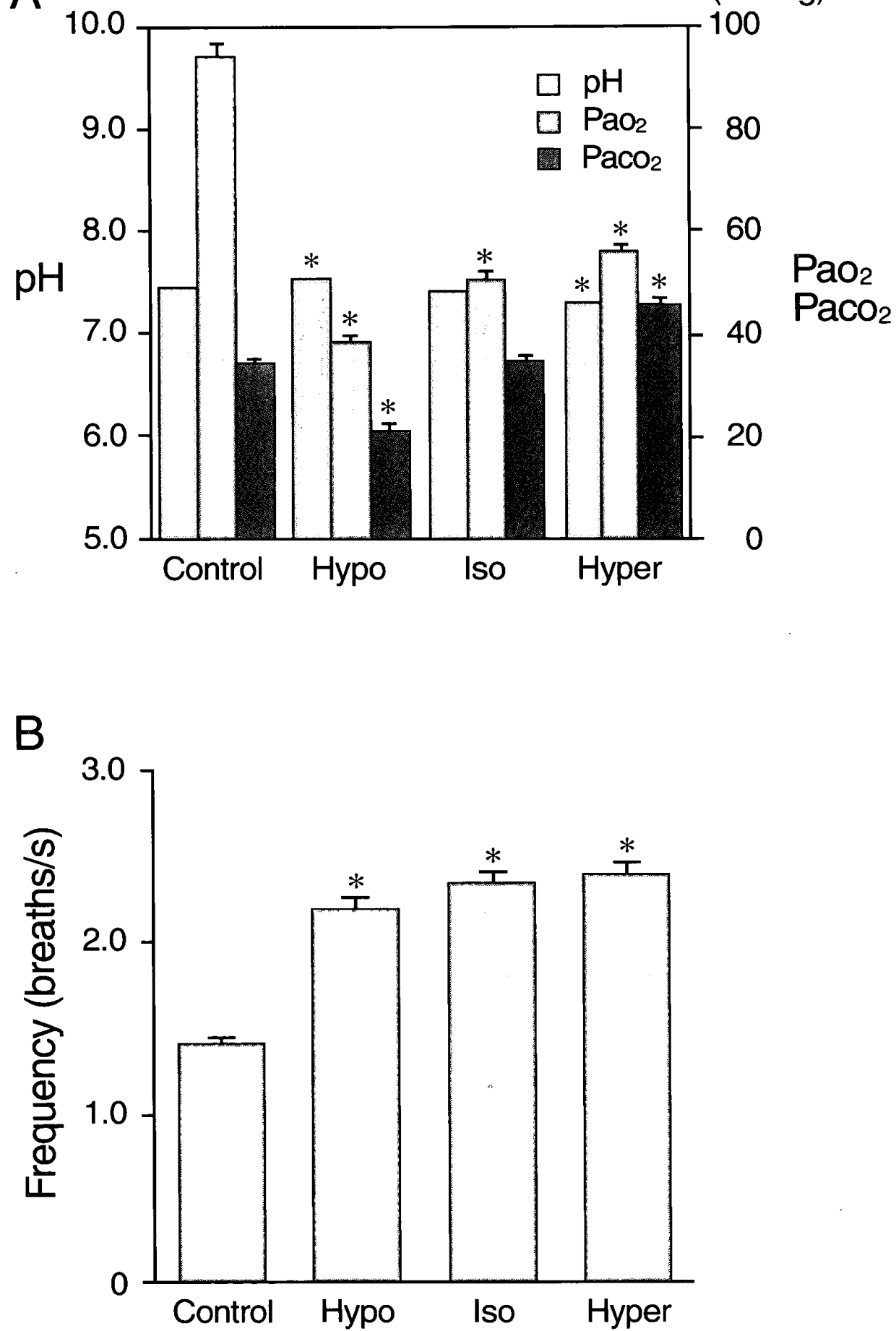

Fig. 1. (A) Arterial blood gas values $\left(\mathrm{pH}, \mathrm{PaO}_{2}\right.$ and $\left.\mathrm{PaCO}_{2}\right)$ and (B) respiratory frequency during the control period and hypoxic (hypocapnic; Hypo, isocapnic; Iso, hypercapnic; Hyper) exposure. Values are means $\pm \mathrm{SE}$.

${ }^{*}$ Significant difference $(P<0.05)$ from control. 

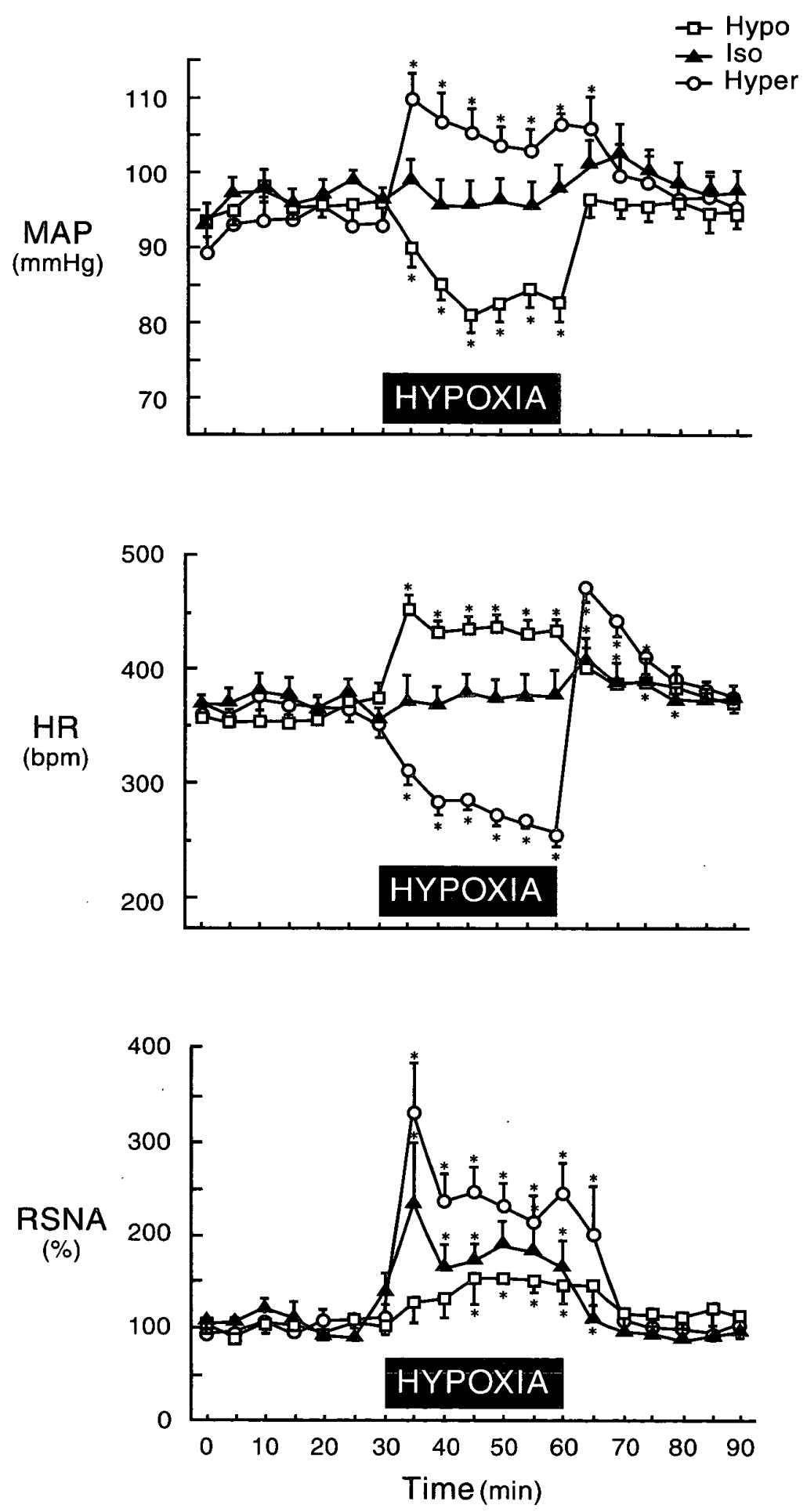

Fig. 2. MAP, HR and RSNA responses to $30 \mathrm{~min}$ of hypocapnic hypoxia (Hypo: $\square$ ), isocapnic hypoxia (Iso: A) and hypercapnic hypoxia (Hyper: $\bigcirc$ ).

Values are means $\pm \mathrm{SE}$.

*Significant difference $(P<0.05)$ from control (average value of $5 \mathrm{~min}$ before the start of exposure). 
control period was $1.41 \pm 0.03$ breaths/sec. Respiratory frequency increased during Hypo, Iso and Hyper ( $2.21 \pm 0.06,2.36 \pm 0.06$ and $2.42 \pm 0.06$ breaths/sec, respectively), and there were no significant differences between these states.

\section{Cardiovascular and autonomic responses to hypoxic exposures}

Fig. 2 shows the mean changes in MAP, HR and RSNA during the control, hypoxic exposure (Hypo, Iso and Hyper) and recovery periods. Iso did not affect MAP(96.0 \pm 2.6 vs $96.6 \pm 1.3 \mathrm{mmHg}$ ), while Hypo decreased MAP from $96.1 \pm 1.9 \mathrm{mmHg}$ to a steady value of 84.3 $\pm 1.0 \mathrm{mmHg}(P<0.05)$ in $10 \mathrm{~min}$, and Hyper increased MAP from $93.1 \pm 2.5 \mathrm{mmHg}$ to $105.8 \pm 1.2 \mathrm{mmHg}(P<0.05)$ in $5 \mathrm{~min}$. MAP returned to the control level in less than 10 min after the end of each hypoxic exposure.

In contrast to MAP responses, HR increased during Hypo (from $373.8 \pm 13.5$ to $436.1 \pm$ $4.2 \mathrm{bpm}, P<0.05)$ in the steady state and returned directly to the control level in $20 \mathrm{~min}$ after the cessation of exposure to the gas. HR did not change significantly during Iso(355.0 \pm 11.9 vs $374.0 \pm 7.6 \mathrm{bpm}$ ), but slightly increased above the control value to $407.8 \pm 19.0 \mathrm{bpm}$ immediately after exposure. HR decreased and reached a steady state in 10 min during Hyper (from $350.8 \pm 9.0$ to $279.9 \pm 4.3 \mathrm{bpm}, P<0.05$ ) and increased to a maximum value of 469.3 $\pm 10.4 \mathrm{bpm}(P<0.05)$ after the cessation of exposure to the gas.

RSNA increased and reached a steady state between 10 and $15 \mathrm{~min}$ during each hypoxia and the magnitude of this increase was proportional to the increase in $\mathrm{PaCO}_{2}$ (Hypo; $152.5 \pm$ $8.7 \%, P<0.05$, Iso; $176.0 \pm 12.0 \%, P<0.05$, Hyper; $235.3 \pm 12.6 \%, P<0.05)$. RSNA returned directly to the control level in $5 \mathrm{~min}$ after the end of each hypoxic exposure.

\section{Discussion}

The present study in rats confirmed that the cardiovascular and autonomic responses to hypoxia depended on $\mathrm{PaCO}_{2}$ : Hypo induced a decrease in MAP and tachycardia, Iso did not induce any significant changes in MAP or HR, and Hyper induced an increase in MAP and bradycardia. RSNA increased during each hypoxia in the steady state. In addition, the present experiments demonstrated that cardiovascular and autonomic responses to hypoxia reached a steady state in $10 \mathrm{~min}$ after the start of exposure. Underlying mechanisms are thought to be: 1) inhibition of parasympathetic nervous system and activation of sympathetic nervous system during Hypo, and 2) co-activation of para- and sympathetic nervous system during Iso and Hyper [9].

In the present experiments, HR increased above the control value after the termination of exposure to the Iso and Hyper conditions. Miki et al. [13] reported that a rebound phenomenon was observed in ABP, HR and RSNA during the recovery phase in conscious dogs after head-out water immersion. They suggested that the rebound of ABP and HR depended on the RSNA response, which might be related to resetting of the high pressure system of the 
baroreflex pathway. A rebound cardiovascular response has also been reported after electrical vagal stimulation (i.e., postvagal tachycardia) $[11,14,15]$. Various hypotheses have been proposed for the underlying mechanisms: liberation of catecholamines from intracardiac adrenergic neurons innervated by vagal fibers [11], activation of sympathetic neural elements present in the vagosympathetic complexes or cardiopulmonary nerves [14].

Burke and Calaresu[15] postulated that postvagal tachycardia was not mediated by sympathetic adrenergic mechanisms, but was related to an increase in net sodium influx into pacemaker cells, since postvagal tachycardia was dependent on the preceding vagal bradycardia. In the present study, HR responses after Iso and Hyper exposure did not parallel the sympathetic nerve response. It has also been previously shown that the sympathetic and parasympathetic nervous systems were activated simultaneously during Iso and Hyper[9]. These results suggest that rebound tachycardia was mediated by the parasympathetic nervous system. Additional indirect evidence of parasympathetic involvement is provided by the abolishment of rebound tachycardia after treatment with atropine as shown in our previous report [9], which agrees with a report that postvagal tachycardia was abolished by atropine [15]. Therefore, rebound tachycardia after hypoxic exposure may be caused by a mechanism similar to that for the HR increase following electrical vagal stimulation, i.e. parasympathetic activation during Iso and Hyper potentiates a positive chronotropic effect, whose persistence leads to a transient increase in HR after withdrawal of the inhibitory effect of parasympathetic activation on the cardiac pacemaker. Our previous study showed that the increase in RSNA coincided with the increase in plasma norepinephrine during hypoxia[9], suggesting that the behavior of RSNA reflects that of the sympathetic nervous system during hypoxia.

The cardiovascular responses in rats during hypoxia observed in this study do not entirely coincide with those in previous studies in various species including humans. Experiments that were carried out in animals with or without anesthetics and artificial ventilation, or with exposure to hypoxia for less than $10 \mathrm{~min}$ are listed in Table 1 . They were conducted under different experimental conditions and had extremely variable results. It is also apparent that the cardiovascular responses evoked by hypoxic stimuli differ not only between species, but also within the same species. This variability of the cardiovascular responses during hypoxia may be due to differences in the experimental design. Anesthesia is known to modify and sometimes reverse cardiovascular and autonomic responses $[23,24]$. Artificial ventilation also modifies the cardiovascular responses induced by chemoreceptor stimulation $[1,3]$. The period of hypoxic exposure may also cause different cardiovascular responses to systemic hypoxia, if the responses are in a transient rather than in the steady state. The respiratory response to hypoxia is known to be biphasic [5]; an initial rapid increase in ventilation followed by a slow decrease to a value above the euoxic level. Furthermore, cadiovascular responses to hypoxia also depend on the intensity of the stimulus $[18,19,22]$ and concomitant changes in $\mathrm{PaCO}_{2}[25-27]$.

Table 2 shows the results of previous experiments using animals in the conscious state and 
Table 1. Previous studies on the cardiovascular responses to systemic hypoxia in animals with or without anesthetics and artificial ventilation, or when exposed to hypoxia for less than $10 \mathrm{~min}$

\begin{tabular}{|c|c|c|c|c|c|c|}
\hline Species & Anesthetics & Ventilation & $\begin{array}{r}\mathrm{O}_{2} \text { level } \\
(\mathrm{mmHg})\end{array}$ & $\begin{array}{c}\mathrm{CO}_{2} \text { level } \\
(\mathrm{mmHg})\end{array}$ & $\mathrm{ABP}$ & HR \\
\hline \multicolumn{7}{|l|}{ Hypo } \\
\hline Human [16] & $(-)$ & $S$ & 47 & 30 & $\uparrow$ & $\uparrow$ \\
\hline $\operatorname{Dog} \quad[17]$ & $(-)$ & $S$ & $<55$ & 18 & $\uparrow$ & $\uparrow$ \\
\hline Cat [18] & $(+)$ & $S$ & $65-30$ & 20 & $\uparrow$ or $\rightarrow$ & $\rightarrow$ or $\uparrow$ or $\downarrow$ \\
\hline$[19]$ & $(+)$ & $S$ & $60-25$ & $30-20$ & $\downarrow$ & $\uparrow$ \\
\hline \multicolumn{7}{|l|}{ Iso } \\
\hline Human [20] & $(-)$ & $S$ & $\left(\mathrm{SaO}_{2}: 82 \%\right)$ & 36 & $\rightarrow$ & $\uparrow$ \\
\hline Dog [21] & $(+)$ & A & 38 & 39 & $\uparrow$ & $\uparrow$ \\
\hline Rat [22] & $(+)$ & A & $\left.\mathrm{FETO}_{2}: 10-6 \%\right)$ & $($ FetcO2 : $5 \%)$ & $\downarrow$ or $\rightarrow$ & $\uparrow$ \\
\hline$[19]$ & $(+)$ & $S$ & $60-30$ & 35 & $\downarrow$ & $\uparrow$ or $\rightarrow$ \\
\hline \multicolumn{7}{|l|}{ Hyper } \\
\hline Human [20] & $(-)$ & $S$ & $\left(\mathrm{SaO}_{2}: 91 \%\right)$ & 55 & $\uparrow$ & $\uparrow$ \\
\hline Dog [17] & $(-)$ & $S$ & $<55$ & 40 & $\uparrow$ & $\uparrow$ \\
\hline Dog & $(+)$ & A & 42 & 71 & $\rightarrow$ & $\rightarrow$ \\
\hline
\end{tabular}

$\mathrm{ABP}$; arterial blood pressure, $\mathrm{HR}$; heart rate, $\mathrm{S}$; spontaneous breathing, $\mathrm{A}$; artificial ventilation,

$\mathrm{SaO}_{2}$; arterial $\mathrm{O}_{2}$ saturation, $\mathrm{FETO}_{2}$ and $\mathrm{FETCO}_{2}$; end-tidal $\mathrm{O}_{2}$ and $\mathrm{CO}_{2}$ concentration.

exposed to hypoxia for more than 10 min: Hypo elicits a decrease in BP and an increase in HR, Iso does not affect BP or HR, and Hyper elicits an increase in BP and a decrease in HR in sheep, rats and humans. These results coincide with our present findings. In contrast, Hypo does not affect BP in dogs $[30-32]$ and rabbits $[25,26]$, nor do Iso and Hyper increase $\mathrm{BP}$ and HR in dogs [7]. In these experiments, hypoxic gas was delivered through tracheal breathing. It has been reported that during hypoxic stimulation, tracheal breathing is associated with a sustained increase in minute ventilation, which was greater than that found during nasal-oral (mask) breathing [34]. It has also been reported that increased respiration reduces the excitability of cardiac vagal motoneurons through an augmented central inspiratory drive and increased activity of pulmonary stretch receptors [1]. Furthermore, other methodological differences may exist. Rose et al.[7] observed excessive ventilatory drive and a 10-fold increase in minute ventilation, which is apparently higher than that in other studies in dogs. Accordingly, the variability of cardiovascular responses among species might reflect differences in the experimental design.

In conclusion, cardiovascular and autonomic responses to systemic hypoxia depended on $\mathrm{PaCO}_{2}$. The termination of hypoxic exposure (Iso and Hyper) induced rebound tachycardia 
Table 2. Previous studies on the cardiovascular responses to systemic hypoxia in unanesthetized spontaneous breathing animals exposed to hypoxia for more than $10 \mathrm{~min}$

\begin{tabular}{|c|c|c|c|c|c|}
\hline Authors & Species & $\begin{array}{l}\mathrm{O}_{2} \text { level } \\
(\mathrm{mmHg})\end{array}$ & $\begin{array}{c}\mathrm{CO}_{2} \text { level } \\
(\mathrm{mmHg})\end{array}$ & $\mathrm{ABP}$ & HR \\
\hline \multicolumn{6}{|l|}{ Hypo } \\
\hline Rowel et al. & Human & 27 & 29 & $\downarrow$ & $\uparrow$ \\
\hline Miki et al. [29] & Sheep & 40 & 25 & $\downarrow$ & $\uparrow$ \\
\hline Overgaard et al. [30] & Dog & 48 & 29 & $\rightarrow$ & $\uparrow$ \\
\hline Heitman et al. [31] & Dog & 47 & 26 & $\rightarrow$ & $\uparrow$ \\
\hline Krebs et al. & Dog & 36 & 27 & $\rightarrow$ & $\uparrow$ \\
\hline Korner & Rabbit & $\left(9 \% \mathrm{O}_{2}\right)$ & 14 & $\rightarrow$ & $\uparrow$ \\
\hline Chalmers et al. [26] & Rabbit & 38 & 16 & $\rightarrow$ & $\uparrow$ \\
\hline Walker $\quad[27]$ & Rat & 32 & 22 & $\downarrow$ & $\uparrow$ \\
\hline \multicolumn{6}{|l|}{ Iso } \\
\hline Rose et al. [7] & Dog & 34 & 32 & $\uparrow$ & $\uparrow$ \\
\hline Raff et al. [33] & Rat & 42 & 37 & $\rightarrow$ & $\rightarrow$ \\
\hline Walker [27] & Rat & 36 & 32 & $\rightarrow$ & $\rightarrow$ \\
\hline \multicolumn{6}{|l|}{ Hyper } \\
\hline Rose et al. [7] & Dog & 35 & 50 & $\uparrow$ & $\uparrow$ \\
\hline Korner $\quad[25]$ & Rabbit & $\left(9 \% \mathrm{O}_{2}\right)$ & 47 & $\uparrow$ & $\downarrow$ \\
\hline Walker $\quad[27]$ & Rat & 35 & 51 & $\uparrow$ & $\downarrow$ \\
\hline
\end{tabular}

$\mathrm{ABP}$; arterial blood pressure, HR; heart rate, $\mathrm{S}$; spontaneous breathing, A; artificial ventilation,

$\mathrm{SaO}_{2}$; arterial $\mathrm{O}_{2}$ saturation.

which was mediated presumably by a parasympathetic mechanism. The cardiovascular responses to systemic hypoxia do not depend on species differences but rather on differences in experimental design.

\section{References}

1. Daly MB (1986): Interactions between respiration and circulation. In: Handbook of Physiology. The Respiratory System. Control of Breathing. Sect 3. vol II. pt 2. Am Physiol Soc, Bethesda, MD pp 529-594

2. Marshall JM (1994): Peripheral chemoreceptors and cardiovascular regulation. Physiol Rev 74 (3): $543-594$

3. Daly MB \& Scott MJ (1958): The effects of stimulation of the carotid body chemoreceptors on heart rate in the dog. J Physiol 144: 148-166 
4. Daly MB \& Scott MJ (1963): The cardiovascular responses to stimulation of the carotid body chemoreceptors in the dog. J Physiol 165: 179-197

5. Painter R, Khamnei S \& Robbins P (1993): A mathematical model of the human ventilatory response to isocapnic hypoxia. J Appl Physiol 74(4): 2007-2015

6 . Korner PI \& White SW (1966): Circulatory control in hypoxia by the sympathetic nerves and adrenal medulla. J Physiol 184: $272-290$

7 . Rose CE Jr, Althaus JA, Kaiser DL, Miller ED \& Carey RM (1983): Acute hypoxemia and hypercapnia: increase in plasma catecholamines in conscious dogs. Am J Physiol 245 (Heart Circ Physiol 14): H 924-929

8. Hayashida Y, Hirakawa H, Nakamura T \& Maeda M (1996): Chemoreceptors in autonomic responses to hypoxia in conscious rats. Adv Exp Med Biol 410: 439-442

9 . Hirakawa H, Nakamura T \& Hayashida Y (1997): Effect of carbon dioxide on autonomic cardiovascular responses to systemic hypoxia in conscious rats. Am J Physiol 273 (Regulatory Integrative Comp Physiol 42): R 747-754

10. Burton AC (1939): The properties of the steady state compared to those of equilibrium as shown in characteristic biological behaviour. J Cell Comp Physiol 14: $327-349$

11. Copen DL, Cirillo DP \& Vassalle M (1968): Tachycardia following vagal stimulation. Am J Physiol 215(3): 696-703

12. Nakamura T, Hirakawa H, Hayashida Y, Nakashima Y \& Kuroiwa A (1996): Detection of respiratory frequency in the recordings of electrocardiogram, blood pressure or sympathetic nerve activity in the conscious rat. J Univ Occup Environ Health 18 : 177-184

13. Miki K, Hayashida Y, Sagawa S \& Shiraki K (1989): Renal sympathetic nerve activity and natriuresis during water immersion in conscious dogs. Am J Physiol 256 (Regulatory Integrative Comp Physiol 25): R 299-305

14. Armour JA \& Randall WC (1985): Rebound cardiovascular responses following stimulation of canine vagosympathetic complexes of cardiopulmonary nerves. Can J Physiol Pharmacol 63: $1122-1132$

15. Burke GH \& Calaresu FR (1972): An experimental analysis of the tachycardia that follows vagal stimulation. J Physiol 226: 491-510

16. Lugliani R, Whipp BJ \& Wasserman K (1973): A role for the carotid body in cardiovascular control in man. Chest 63(5): 744-750

17. Koehler RC, McDonald BW \& Krasney JA (1980): Influence of $\mathrm{CO}_{2}$ on cardiovascular response to hypoxia in conscious dogs. Am J Physiol 239 (Heart Circ Physiol 8): H 545-558

18. Marshall JM \& Metcalfe JD (1989): Analysis of factors that contribute to cardiovascular changes induced in the cat by graded levels of systemic hypoxia. J Physiol 412: 429-448

19. Marshall JM \& Metcalfe JD (1988): Analysis of the cardiovascular changes induced in the rat by graded levels of systemic hypoxia. J Physiol 407: 385-403

20. Somers VK, Mark AL, Zavala DC \& Abboud FM (1989): Influence of ventilation and hypocapnia on sympathetic nerve responses to hypoxia in normal humans. J Appl Physiol 67(5): 
21. Rothe CF, Maass-Moreno R \& Flanagan AD (1990): Effects of hypercapnia and hypoxia on the cardiovascular system: vascular capacitance and aortic chemoreceptors. Am J Physiol 259 (Heart Circ Physiol 28): H 932-939

22. Fukuda Y, Sato A, Suzuki A \& Trzebski A (1989): Autonomic nerve and cardiovascular responses to changing blood oxygen and carbon dioxide levels in the rat. J Auton Nerv Syst 28: $61-74$

23. Walker LA, Buscemi-Bergin M \& Gellai M (1983): Renal hemodynamics in conscious rats: effects of anesthesia, surgery, and recovery. Am J Physiol 245 (Renal Fluid Electrolyte Physiol 14): F $67-74$

24. Nakamura T \& Hayashida Y (1992): Autonomic cardiovascular responses to smoke exposure in conscious rats. Am J Physiol 262 (Regulatory Integrative Comp Physiol 31): R 738-745

25. Korner PI (1965): The role of the arterial chemoreceptors and baroreceptors in the circulatory response to hypoxia of the rabbit. J Physiol 180: 279-303

26. Chalmers JP, Korner PI \& White SW (1967): The relative roles of the aortic and carotid sinus nerves in the rabbit in the control of respiration and circulation during arterial hypoxia and hypercapnia. $\mathrm{J}$ Physiol 188: $435-450$

27. Walker BR (1986): Role of vasopressin in the cardiovascular response to hypoxia in the conscious rat. Am J Physiol 251 (Heart Circ Physiol 20): H 1316-1323

28. Rowell LB \& Blackmon JR (1986): Lack of sympathetic vasoconstriction in hypoxemic humans at rest. Am J Physiol 251 (Heart Circ Physiol 20): H 562-570

29. Miki M, Miki K, Hajduczok G, Curran-Everett D \& Krasney JA (1987) : Control of arterial pressure in conscious, sinoaortic-denervated sheep in normoxia and hypoxia. Am J Physiol 253 (Heart Circ Physiol 22): H 1409-1417

30. Overgaard CB, Walker JKL \& Jennings DB (1996): Respiration during acute hypoxia: angiotensin and vasopressin-receptor blocks. J Appl Physiol 80(3): 810-817

31. Heitman SJ \& Jennings DB (1998): Angiotensin II modulates respiratory and acid-base responses to prolonged hypoxia in conscious dogs. Am J Physiol 275 (Regulatory Integrative Comp Physiol 44): R 390-399

32. Krebs MO, Boemke W, Simon S, Wenz M \& Kaczmarczyk G (1999): Acute hypoxic pulmonary vasoconstriction in conscious dogs decreases renin and is unaffected by losartan. J Appl Physiol $86(6): 1914-1919$

33. Raff $\mathrm{H} \&$ Fagin $\mathrm{KD}$ (1984): Measurement of hormones and blood gases during hypoxia in conscious cannulated rats. J Appl Physiol 56(5): 1426-1430

34. Cao K-Y, Sullivan CE, Berthon-Jones M \& Zwillich CW (1993): Breathing route and resistive loading: influence on ventilatory response to hypoxia in conscious dogs. J Appl Physiol 75(3): $1247-1255$ 
低酸素による自律神経・循環反応の解析：反跳現象と種差について

平川 晴久, 林田 嘉朗

産業医科大学産業生態科学研究所 応用生理学教室

要旨：低酸素によって引き起こされれる自律神経系と循環系の反応、および暴露直後にみら れる心拍の反跳現象について解析を行った.

血圧測定用カテーテル，心電図そして腎交感神経活動記録用電極を慢性に植え込ん だ Wistar ratを用い, hypocapnic (Hypo), isocapnic (Iso), hypercapnic (Hyper) hypoxia の暴露を行った．Isoでは，血圧及び心拍数は変化しなかったが, Hypoでは, 血圧 は低下し心拍数は增加, Hyperでは, 血圧は上昇し心拍数は低下した。腎交感神経活 動はいずれにおいても増加した. Iso と Hyperの終了直後, 心拍数は一過性に増加し た。この心拍反応は，腎交感神経活動の反応とは相関しなかった。このことより， この心拍の反跳現象は，交感神経よりもむしろ副交感神経系のメカニズムによるも のと考えられた.

低酸素時の循環反応は動物により異なると考えられているが，類似した条件におい て行われた実験においては種差に関わらず，その結果は，ほほ一致するものであった。

J UOEH（産業医大誌）24（2）:117-129（2002） 